\section{Ecotoxicological Tests in Winogradsky Columns Contaminated by Used Lubricating Oil and Biodiesel}

\author{
Karen Hosomi Teramae \\ UNESP - Univ Estadual Paulista, Av. 24A, 1515 - Bela Vista \\ Postal Code: 13506-900 Rio Claro-SP, Brazil \\ Tel: (55)19-3526-4191Ｅ-mail: karenteramae@gmail.com
}

Mariana Lopes de Sousa

UNESP - Univ Estadual Paulista, Av. 24A, 1515 - Bela Vista

Postal Code: 13506-900 Rio Claro-SP, Brazil

Tel: (55)19-3526-4191 E-mail: maree_mitsu@yahoo.com.br

Dejanira de Fransceschi de Angelis

UNESP - Univ Estadual Paulista, Av. 24A, 1515 - Bela Vista

Postal Code: 13506-900 Rio Claro-SP, Brazil

Tel: (55)19-3526-4191_E-mail: dangelis@rc.unesp.br

\author{
Ederio Dino Bidoia (Corresponding Author) \\ UNESP - Univ Estadual Paulista, Av. 24A, 1515 - Bela Vista \\ Postal Code: 13506-900 Rio Claro-SP, Brazil \\ Tel: (55)19-3526-4191 E-mail: ederio@rc.unesp.br
}

Received: September 4, 2012 Accepted: September 20, 2012

doi:10.5296/emsd.v1i2.2513 URL: http://dx.doi.org/10.5296/emsd.v1i2.2513 


\section{Abstract}

The lubricating oil is among the few oil products that are not fully consumed during use. Formulators of lubricants have been working on developing products with longer life. However, with increasing additives and life, there are more difficulties in the regeneration process after use. Moreover, in Brazil 64\% of used lubricating oil disposal is inadequate. Biodiesel consists of an alternative to petroleum diesel because it emits less greenhouse gases in the combustion process. However, it is not an ideal fuel, because the main renewable source for biodiesel production is soy, whose cultivation requires large areas available, which often were deforested. In addition, there is no knowledge about the real effects in case of leaks biodiesel front of groundwater quality, human health and the environment. The Winogradsky column is a glass container containing samples of soil, water and nutrients from the environment, which you want to play. This study aimed to use the Winogradsky column in the analysis of biota from an aquatic ecosystem contaminated with mineral lubricating oil or biodiesel used. The methodology of the Winogradsky column to have an ecotoxicological assessment of the river Ribeirão Claro water contaminated with used lubricating oil or biodiesel. Algae were used as bioindicators of the water's quality and toxicity with the help of identification keys.

Keywords: Winogradsky, sulfur-reducing bacteria, algae, bioindicators, toxicity

\section{Introduction}

Only 1 liter of lubricating oil is enough to contaminate one million liters of water (Atlas et al., 1991). The lubricating oil used has good degradability due to the action of compression and heat inside the car engines, leading to the breakdown of large carbon chains, which makes it less polar. Therefore, the lubricating oil used is biodegradable as well, but has heavy metals and formation of dark color in the water because of waste oil burned (Brasil, 2001; Montagnolli et al., 2009).

Biodiesel is derived from renewable biomass and, according to Gomes (2008), it is not known what are the real effects in case of leaks or spills of biodiesel on the water's quality and if the risk to human health and the environment is tolerable. Therefore, based on the promise that biodiesel is a substituent of diesel, oil biodegradation studies in aquatic ecosystems are essential and aims to evaluate their degradation time, the degree of toxicity to the biota and the physical-chemical their degradation in case of accidents.

An effective way to simulate an aquatic ecosystem and tracks the changes that occur in the biota against pollution caused by used lubricating oil or biodiesel is the Winogradsky column. It consists of a glass container containing samples of soil, water and nutrients from the environment, which you want to play. Inside the column is possible to monitor the occurrence and distribution of microorganisms and to infer the role of microbiota in each of the water's body (NASA, 2001).

A contaminated environment requires measures to be taken to ensure that pollutants are removed. Thus, a viable alternative in the applicability of remediation techniques is the environmental degradation that occurs through the enzymatic action of microorganisms, 
which convert organic chemicals by changing their molecular structures (Alexander, 1981; Atlas et al., 1991; Crapez, 1982). The process can be limited by several factors: the presence of nutrients, composition of the biota, salinity, dissolved oxygen concentration in the water, temperature and nature of the pollutant. The algae that develop in Winogradsky columns can be used as bioindicators of ecological quality of water, they are easily sampled, have a cosmopolitan distribution, pollutants accumulate in your cells and may be reproduced in the laboratory. A criterion of pollution has been suggested, based on the kinds of algae present in aquatic systems: the less diverse the population, the higher the contamination of the system (Trainor \& Shubert, 1983).

\section{Methods}

The first step was to collect water and soil in the river "Ribeirão Claro" on ETA DAAE in Rio Claro, Brazil, situated $7519653.42 \mathrm{~m} \mathrm{E}$ and $238489.31 \mathrm{~m} \mathrm{~S}$ in UTM coordinates. The water in this stretch of the stream had good quality, verified by the high diversity of organisms, compared to other environments impacted by anthropogenic activities (Barbosa \& Callisto, 2000).

The used lubricating oil was collected in local exchange (local specialized) with no brand or type of oil. And biodiesel (B100) was obtained from the Food Caramuru S. A. (GO), a producer of biodiesel.

\subsection{Preparation of inoculum}

In the first stage of the process, Bacillus subtilis ATCC 6633 was kept under refrigeration $\left(4^{\circ} \mathrm{C}\right)$ in agar nutrient according to the Difco Manual (1984). The bacillus was then revived in agar nutrient broth. The bacteria grown in an incubator with agitation at $180 \mathrm{rpm}$ for 24 hours and the resulting liquid inoculum (105 to 106 colony forming units $/ \mathrm{mL}$ ) was stored under refrigeration.

\subsection{Winogradsky columns}

Winogradsky columns were prepared with water and soil of the river "Ribeirão Claro" in glass containers of $500 \mathrm{~mL}$ including nutrients $\left(0.2 \mathrm{~g}\right.$ of $\mathrm{Na}_{2} \mathrm{CO}_{3}, 4.5 \mathrm{~g}$ of $\mathrm{Na}_{2} \mathrm{SO}_{4}, 0.5 \mathrm{~g}$ of $\mathrm{KH}_{2} \mathrm{PO}_{4}, 0.2 \mathrm{~g}$ of $\left(\mathrm{NH}_{4}\right)_{2} \mathrm{SO}_{4}$, and $0.5 \mathrm{~g}$ of A4 paper cut to serves as a source of cellulose). The concentration of salts in water was $10.8 \mathrm{~g} / \mathrm{L}$, simulating a brackish water environment. The nutrients were added according to Sousa et al. (2012) and the columns were prepared as follows:

- Column I: 100 g of soil, 500 mL of water from the river "Ribeirão Claro";

- Column II: $100 \mathrm{~g}$ of soil, $495 \mathrm{~mL}$ of water and $5 \mathrm{ml}$ of Tween 80 surfactant;

- Column III: $100 \mathrm{~g}$ of soil, $490 \mathrm{~mL}$ of water, $5 \mathrm{~mL}$ of biodiesel and $5 \mathrm{~mL}$ of Tween 80 surfactant;

- Column IV: $100 \mathrm{~g}$ of soil, $490 \mathrm{~mL}$ of water, $5 \mathrm{~mL}$ of used lubricating oil and $5 \mathrm{ml}$ of Tween 80 surfactant; 


\section{Macrothink}

- Column V: $100 \mathrm{~g}$ of soil, $485 \mathrm{~mL}$ of water, $5 \mathrm{~mL}$ of biodiesel and $5 \mathrm{~mL}$ of the surfactant Tween 80 and $5 \mathrm{~mL}$ of liquid inoculum of Bacillus subtilis;

- Column VI: $100 \mathrm{~g}$ of soil, $485 \mathrm{~mL}$ of water, $5 \mathrm{~mL}$ of used lubricating oil and $5 \mathrm{~mL}$ of the surfactant Tween 80 and $5 \mathrm{~mL}$ of liquid inoculum of Bacillus subtilis.

The inoculum of $B$. subtilis was added in the last two columns to allow a comparison of the bioremediation of contaminants in the presence and absence of the bacillus.

The chemical surfactant Tween 80 (Polysorbate 80) was added to enhance biodegradation of contaminants in different ecosystems.

After 1 month of installation of the columns, when the phytoplankton population was stabilized, the water samples were collected from the three strata in microecossistema: top, middle and floor. These strata correspond to the aerobic zones, microaerophilic and anoxic, respectively.

The samples were identified, conditioned in a test tube with water and alcohol and kept under refrigeration for later use.

Three slides were mounted for each zone, with the purpose of sampling significantly phytoplankton community of the columns. For the identification of algae was used Nikon optical microscope. Algae were identified using taxonomic keys (Bicudo \& Menezes, 2006) and compared the material with boards of genres. We tried to identify all the genera found in each slide.

\subsection{Toxicity test, using seeds of Lactuca sativa (lettuce) and Cucumis sativus (cucumber)}

Ecosystems of the Winogradsky columns represent brackish water environments. Consequently, the salinity could affect seed germination and thus we could not determine the actual influence of toxic contaminants in the water. Therefore, it was performed the toxicity test to determine the influence of different concentrations of nutrients in water, without pollutants, on the germination of Lactuca sativa and Cucumis sativus.

The original concentration (Co) of nutrients, present in all the Winogradsky columns, was $10.8 \mathrm{~g} / \mathrm{L}$. It was determined that for this acute toxicity test, the result would be more expressive with the use of various dilutions of brackish water. Therefore, were used five different concentrations, as described below:

- Co: Original concentration, corresponding to $10.8 \mathrm{~g} / \mathrm{L}$;

- $\mathrm{Co} / 2$ : Half of the original concentration, corresponding to $5.4 \mathrm{~g} / \mathrm{L}$;

- Ca: Concentration of freshwater environments, corresponding to $3.9 \mathrm{~g} / \mathrm{L}$;

- $\mathrm{Co} / 3$ : A third of the original concentration, corresponding to $3.6 \mathrm{~g} / \mathrm{L}$;

- $\mathrm{Co} / 4$ : One-fourth of the original concentration, corresponding to $2.7 \mathrm{~g} / \mathrm{L}$.

To make the solution unique brackish water took the following nutrients: $0.1 \mathrm{~g} \mathrm{Na}_{2} \mathrm{CO}_{3}, 0.1 \mathrm{~g}$ of $\left(\mathrm{NH}_{4}\right)_{2} \mathrm{SO}_{4}, \mathrm{Na}_{2} \mathrm{SO}_{4} 2.25 \mathrm{~g}$ and $0.25 \mathrm{~g}$ of $\mathrm{KH}_{2} \mathrm{PO}_{4}$. 


\section{Macrothink}

Nutrients were added to $250 \mathrm{~mL}$ with water from the river Ribeirão Claro, in a beaker of 250 $\mathrm{mL}$. Five volumetric flasks $(50 \mathrm{~mL})$ were used for the different concentrations.

Of the 12 plates of $100 \times 20 \mathrm{~mm}$, containing the filter paper were prepared 6, each with 50 seeds of L. sativa and other 6, each containing 50 seeds of C. sativus. Of these 12 boards, 2 were used as controls, with mineral water.

Each of the 5 plates containing 50 seeds of $L$. sativa received $1.5 \mathrm{~mL}$ of saline solution with a separate concentration. The same procedure was performed for 5 plates containing seeds of $C$. sativus.

Ready plates were covered with a glass cover next to the window and in contact with sunlight for 24 hours. After this period, $1 \mathrm{~mL}$ of each solution was injected into their corresponding plate. After 48 hours, the germinated seeds were counted.

Abbott's formula provides the percentage of inhibition of germination (Nakano et al. 1981). The adapted formula, described below, calculates the percentage of inhibition (\% I), from the number of seeds germinated in control (C) and the number of seeds germinated in the treatment $(\mathrm{T})$, according to the equation 1 below:

$$
Q_{0} \mathrm{I}=\frac{\mathrm{C}-\mathrm{T}}{\mathrm{C}} \times 100
$$

Ecotoxicological evaluations classify the salt concentration as toxic (over $40 \%$ inhibition of germination), low toxicity (inhibition of germination of $10 \%$ to $40 \%$ ) and non-toxic inhibition to $10 \%$ (Barbosa \& Callisto, 2000).

\section{Results and Discussion}

\subsection{Development of algae and SRB (sulphate reducing bacteria) in Winogradsky columns}

One month after the beginning of the experiment with the columns, there was a dark color in the water columns II, IV and VI, due to the accelerated development of sulfur-reducing bacteria.

During the metabolism of SRB (sulphate reducing bacteria), the sulfate is reduced to hydrogen sulfide $\left(\mathrm{H}_{2} \mathrm{~S}\right)$, which together with ferrous iron $\left(\mathrm{Fe}^{2+}\right)$ present in the sludge promotes the formation of a black precipitate, ferrous sulfide (FeS). The darkening of the water by the formation of FeS is indicative of the metabolic activity of SRB (Barbosa, 2009).

Two months after mounting the columns, there was a dark color of the water's columns except the column control, because the dominance of SRB, which grew primarily in anaerobic stratum of the water body and subsequently proliferated in the sense of the aerobic zone. The main source of sulfate used by these bacteria was found in $\left(\mathrm{NH}_{4}\right)_{2} \mathrm{SO}_{4}$ and $\mathrm{Na}_{2} \mathrm{SO}_{4}$, nutrients added to the beginning of the experiment. 


\section{Mll Macrothink}

The fact of SRB have not been developed in the column control is justified by the absence of Tween 80 in its composition. Therefore, Tween 80 was used as carbon source for sulfur-reducing bacteria.

The mechanisms of bacterial sulfate reduction are directly related to the oxidation of organic matter. In the anoxic zone, the mineralization of organic carbon involves a complex series of degradation and requires the interaction of different groups of microorganisms (Barbosa, 2009).

The success of the species of SRB is related to the origin and concentration of organic substrate and sulfate ions in the environment. For this reason, the SRB grew faster in columns with the lubricating oil used than in the columns containing biodiesel, after all the lubricating oil used has degradation products of base oil and carbon particles originating from the cracking of fuel components that also served as a source of carbon and organic matter to the SRB.

Could be identified sulfur-reducing bacteria of the genus Desulfovibrio spp. This genus often develops between $25^{\circ} \mathrm{C}$ and $44^{\circ} \mathrm{C}$ in a very wide range of $\mathrm{pH}$ ranging from 5.5 to 9 . Withstand high salt concentrations, require reducing conditions for their growth very severe and do not form spores.

Three months after mounting the columns, the interior walls of the tubes began to show a purple coloration. They are easily detectable because they have relatively large cells with sulfur granules inside.

The diffusion of $\mathrm{H}_{2} \mathrm{~S}$ through the water column allowed the growth of these purple bacteria, which produce their cellular materials from $\mathrm{CO}_{2}$. These bacteria do not produce $\mathrm{O}_{2}$ during the photosynthesis process, for use as a reducing $\mathrm{H}_{2} \mathrm{~S}$ and not the water in the production of $\mathrm{S}$.

\subsection{Results of $\mathrm{pH}$ analysis}

The three $\mathrm{pH}$ measurements performed for each zone of all the columns were made in three periods: the first day of the mounting the columns (T0), the second, one month after mounting (T1) and third, two months after the mounting (T2).

Only the $\mathrm{pH}$ of the column I was constant and neutral at the bottom, in the course of two months. This result is consistent with her being the only one, whose dominance of biota did not SRB, since these bacteria release hydrogen sulfide $\left(\mathrm{H}_{2} \mathrm{~S}\right)$, which in turn dissociates into disulfide ( $\mathrm{HS}^{-}$), a conjugate base of $\mathrm{H}_{2} \mathrm{~S}$.

Columns II and III, the $\mathrm{pH}$ varied more than $\mathrm{T} 1$ to $\mathrm{T} 2$, and initially the $\mathrm{pH}$ of both was neutral. In column VI, the $\mathrm{pH}$ increased steadily each month. However, except for the control, all columns had basic $\mathrm{pH}(\mathrm{pH} \geq 8)$ in $\mathrm{T} 2$.

The SRB were found more frequently in the floor of the columns than in any other stratum, because they need the organic matter present in greater amounts in the sludge as carbon source. In addition, the floor of the column is usually the anaerobic zone, which favors the 
growth of these bacteria and therefore, the presence of disulfide in water, which contributes to the medium becomes more basic.

In the central column the table of $\mathrm{pH}$ has a slightly different background. In some columns, the SRB is not fully colonized the layer and therefore the reduction of sulfate and subsequent dissociation reaction of hydrogen sulfide to disulfide did not occur.

Column I stayed with a neutral $\mathrm{pH}$ in all periods measured. Columns II, VI, V and VI followed almost the same growth $\mathrm{pH}$ values found for the background, which means greater presence of SRB in the central zone of these columns. Since the column III, showed pH values lower than the bottom, which means a smaller presence of the anion, HS- in this stratum.

If the $\mathrm{pH}$ increases or remains the basic surface, means it can occur at the top of the column, the dissociation of $\mathrm{H}_{2} \mathrm{~S}$ to $\mathrm{HS}^{-}$. It could be an indication that an anaerobic situation formed on the surface due to the oil, which does not leave the water with more dissolved oxygen. This is the case of column IV, which in this case simulates an oil spill. This would bring serious consequences for aquatic biota dependent on $\mathrm{O}_{2}$, in a real situation.

Interesting results were obtained in columns $\mathrm{V}$ and VI (both contaminated with used lubricating oil and biodiesel, respectively). If the oil causes the anaerobic situation, it favors the development of SRB, which produce $\mathrm{H}_{2} \mathrm{~S}$, which in turn can dissociate into $\mathrm{HS}^{-}$or even sulfide $\left(\mathrm{S}^{2-}\right)$ in extremely alkaline, even leaving the middle more basic. However, if the $\mathrm{pH}$ values of the columns V and VI decreased, the period T1 to T2, this could be an indication that there was a break in the barrier of oil on the surface. And coincidentally, it happened in the columns that received the inoculum of Bacillus subtilis.

Columns V and VI of both contaminants showed $1 \mathrm{~mm}$ thick, and at the beginning of the experiment the used lubricating oil and biodiesel were $4 \mathrm{~mm}$. Therefore, the result may be an indication that the $B$. subtilis produced surfactin, which partially degrade pollutants, when the $\mathrm{pH}$ of the surface region of the columns had to be neutral. As already mentioned, the surfactin has the advantage of molecular unchanged at the change in $\mathrm{pH}$. However, its optimal activity occurs when the $\mathrm{pH}$ is neutral.

In columns III and IV did not occur to decrease the $\mathrm{pH}$ value. It remained neutral on the surface of the column III and most basic was at the top of column IV. When measuring the thickness of the contaminants, it had $1.5 \mathrm{~mm}$ in column III of biodiesel and lubricating oil 3 $\mathrm{mm}$ in column IV. In this case, the biodegradation of biodiesel may have been partly due to the effect of surfactant Tween 80. In column IV, the lubricating oil used showed no significant change in the measure of its thickness.

\subsection{Acute toxicity test}

The amount of $C$. sativus with visible radicles was higher than the number of seeds of $L$. sativa germinated. This occurred because the endosperm $C$. sativus is greater and therefore the availability of reserve material for the growth of the embryo had a direct relation to the 


\section{Macrothink}

size of the albumen. Endosperm cells have all the apparatus for the enzymatic synthesis and seed germination in favorable environmental conditions.

Figure 1 confirms the hypothesis that the salt concentration was the limiting factor for seed germination. The more diluted the set of nutrients, and salts lower the concentration and the greater the number of germinated seeds.

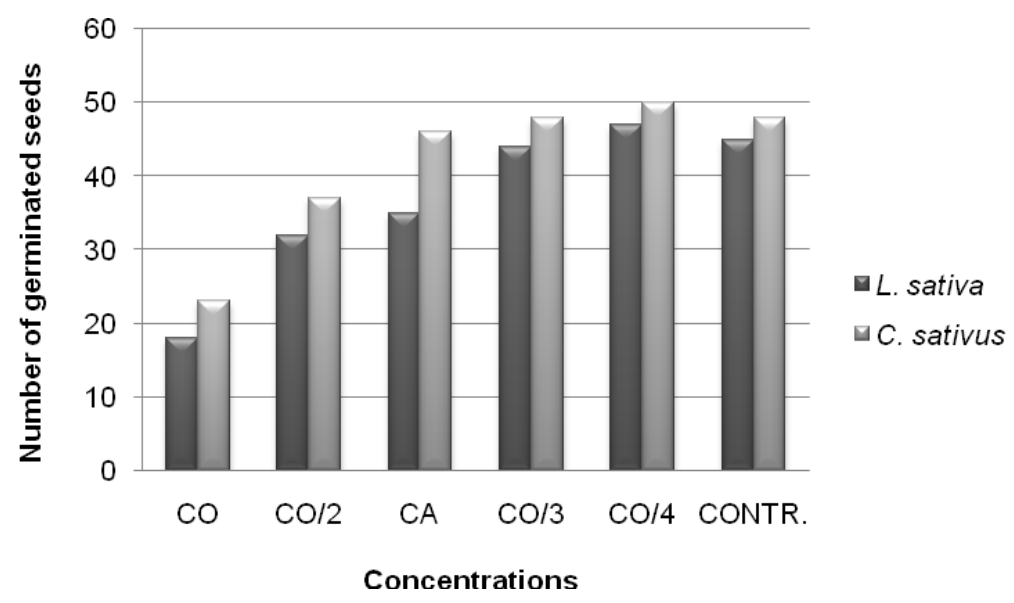

Figure 1. Relationship between the amount of seeds germinated and the concentrations of salts in the water

To check the level of toxicity of each concentration was calculated as percentage of inhibition. According to Figure 2, can be inferred that the original salt concentration of $10.8 \mathrm{~g} / \mathrm{L}$, present in all the columns of Winogradsky, is considered toxic, both for the seeds of L. sativa, and for the seeds of $C$. sativus.

Half of the original concentration $(\mathrm{CO} / 2)$, corresponding to $5.4 \mathrm{~g} / \mathrm{L}$, is classified as being of low toxicity to both species. As for $\mathrm{Ca}$, concentration of nutrients found in freshwater environments of $3.9 \mathrm{~g} / \mathrm{L}$ showed only low toxicity to $L$. sativa.

The two saline solutions $\mathrm{CO} / 3$ and $\mathrm{CO} / 4$, corresponding to $3.6 \mathrm{~g} / \mathrm{L}$ and $2.7 \mathrm{~g} / \mathrm{L}$, respectively, showed no toxicity to both species.

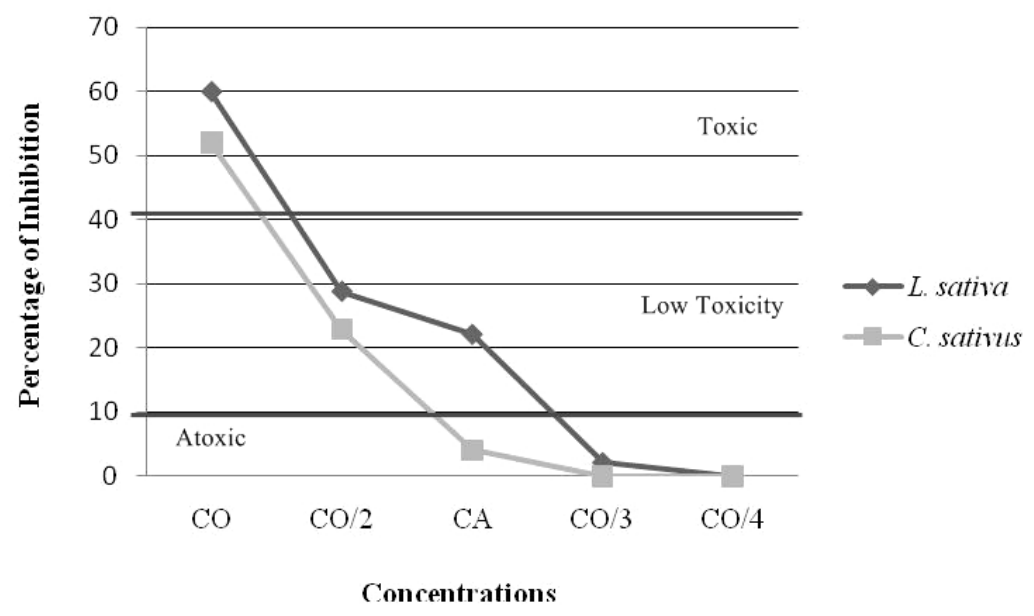

Figure 2. Characterization of concentrations, according to the percentage of inhibition 


\subsection{Algae}

It was identified different kinds of algae in areas of all three columns. A large number of cyanobacteria and green algae were present, especially in the control column.

In the control column was found the largest number of algae, both of cyanobacteria, and green algae. The genera identified in column I, 27 characterize clear environments, as is the case of Calothrix spp., Ulothrix spp., Heteroleibleinia spp., Aphanothece spp., Microcoleus spp., Pseudanabaena spp. and Chroococcus spp was the most representative in terms of abundance. It is a cosmopolitan genus, common in plankton and metafiton in several environments, including brackish water.

In column II, were found only five genera that characterize aquatic clear at the top and middle of the column. While presenting a very small number of individuals were identified: Aphanochaete spp., Gloeothece spp., Johannesbaptistia spp., Leibleinia spp. and Microsporida spp. Genus Snowella spp., Found at the top and middle column, is commonly found in brackish water plankton or sweet and can also live in metaphyton (Franceschini et al., 2010).

In column III was not found any kind of algae that often grow in clear water. This is due to the presence of biodiesel on the water surface, which blocks the passage of oxygen, producing an anaerobic zone at the top of the column, which favors the appearance of SRB, such as Desulfovibrio spp., which in turn deposits sulfur granules inside, resulting in dark water coloration and preventing the passage of light. Therefore, the development of algae is compromised. However, other genera were found bioindicators of contaminated environments, with more representation in the abundance of individuals: Arthrospira spp., Chlorococcum spp. and Gomphonema spp. The genus Botryococcus spp., found at the top and middle of the column can appear in moderately alkaline waters, including oligotrophic to eutrophic waters and lightly salted (Franceschini et al., 2010).

In column IV was not found a large amount of algae because the presence of contaminant, in the case, the lubricating oil used on the surface of the column. The sampled individuals belonged to genera which, in most cases, are representative of polluted waters, they are: Arthrospira spp., Chlorococcum spp., Gomphonema spp. and Nitzsche spp. (top and middle of the column).

Column V presents three individuals of the genus Chroococcus spp. in the central body of water. This genus is characteristic of clear waters. However, other genera were found bioindicators of contaminated environments, with more representation in the abundance of individuals: Arthrospira spp., Chlorococcum spp. and Gomphonema spp.

We identified four representative genera of algae contaminated water column VI: Chlorococcum spp., Nitzsche spp., Chlorella spp. and Gomphonema spp. Also found were two individuals of Aphanizomenon spp. This genus developed in eutrophic environments and can cause blooms (Parra \& Bicudo, 1995). Some species produce toxins, which can affect the natural dynamics of the biota. 


\section{Conclusion}

This work can conclude that there were large changes in the biota of the columns. And one of the principal changes was the development of sulfate-reducing bacteria (SRB), which had focus on research, because of the dominance relationship established by the population of SRB. The fast change in color of the water indicated the growth of these bacteria, provided with sulfur granules deposited inside or outside their cells. The SRB is very important for the maintenance cycles of sulfur and carbon and are the beginning of microbial dynamics in the Winogradsky column, because their metabolic products are enjoyed by other microorganisms, participating in this consortium of different ecosystem functions performed by bacteria, protozoa algae and others microorganisms.

The surfactant Tween 80 included in the methodology with the purpose of enhancing the process of biodegradation of contaminants, served as the carbon source for the SRB, together with organic matter present in sludge. The nutrients added to the columns furnished the sulfate necessary to metabolism of SRB and reproduced a brackish water ecosystem. Because the water has a higher salt concentration than the fresh water, algae that settled in the columns are also found in brackish waters.

Later, appeared purple and green photosynthetic bacteria, which used the products of the metabolism of other SRB to develop.

The microbial activity in columns, added to the conditions of salinity and the presence of contaminants in some columns, resulted in significant changes in the $\mathrm{pH}$ of the water.

In the columns $\mathrm{V}$ and VI, both contaminated with used lubricating oil and biodiesel, respectively, there was a decrease in $\mathrm{pH}$ value after a period of alkaline water. This, added to the fact that the thickness of the contaminants has decreased the course of two months, produces evidence that there was part biodegradation of pollutants through the combined action of Bacillus subtilis, with the aquatic biota and the surfactant Tween 80. However can not be conclude that the main factor for the occurrence of biodegradation in the production of surfactin by $B$. subtilis. Because the network of interactions between the diverse biota and the environment is very complex and full of reactions caused by the microbial consortium.

As for toxicity tests conducted with the seeds of L. sativa and C. sativus, could infer that the concentration of salts in the water was responsible for the inhibition of germination, because the hypertonic environment does not allow the seeds to absorb water. There was an inverse relationship between the value of the concentrations and the rate of seed germination. The presence of oil is another limiting factor for germination, since it waterproof coat and do not allow for the passage of nutrients and water to the seed.

Finally, the use of algae as bioindicators showed to be a very effective technique for determining water quality. In the control column and in the most superficial of columns devoid of contaminant, the genera of algae sampled indicated good water quality, while in columns contaminated appeared algae typical of polluted environments. The number of genera and individuals found concentrated in the column control because the darkening water 
of the other columns did not allow the actual process of photosynthesis, necessary for the development of photosynthetic algae in the environment.

\section{Acknowledgments}

The authors thank FAPESP, CAPES, CNPq and UNESP-Rio Claro for support.

\section{References}

Alexander, M. (1981). Biodegradation of chemicals of environmental concern. Science, 11, 132-138. http://dx.doi.org/10.1126/science.7444456

Atlas, R. M.; Horowitz, A.; Krichevsky, M. (1991). Response of microbial population to environmental disturbance. Microbial Ecolology, 22, 1157-1165. http://dx.doi.org/10.1007/BF02540227

Barbosa, F. A. R.; Callisto, M. (2000). Rapid assessment of water quality and diversity of benthic macroinvertebrates in the upper and middle Paraguay river using the Aqua-RAP approach. Verhandlungen des Internationalen Verein Limnologie, 27, 2688-2692.

Barbosa, L. P. (2009). Cultivo de bactérias redutoras de sulfato (BRS) e sua aplicação na biorremediação de efluentes ácidos contendo metais. Ouro Preto, Brazil, 115 p. (M. Sc. Dissertation. Universidade Federal de Ouro Preto).

Bicudo, C. E. M. \& Menezes, M. (2006). Algae genus from Brazil's landwater: identification key and descriptions ( $2^{\text {nd }}$. ed.). São Carlos: Rima.

Brasil, A. (2001). Óleo Lubrificante. Meio Ambiente e Indústria (31) 1. http://dx.doi.org/10.1049/cp:20010690

Crapez, M. A. C. (1982). Isolement à Partir du Sol et Bactéries Aérobies Sporullées Dégradant Composés Aromatiques. France, 76p. (PhD Thesis, Université D’Aix-MarseilleII).

Difco. (1984). Difco Manual (1 ${ }^{\text {st }}$. ed.). Detroit: Difco Laboratories.

Franceschini, I.M.; Burliga, A.L.; Reviers, B.; Prado, J.F.; Rézig, S.H. (2010) Algas - Uma abordagem filogenética, taxonômica e ecológica (1 ${ }^{\text {st }}$. ed.). Rio de Janeiro: Artmed Editora S.A.

Gomes, A. P. N. (2008). Biodegradação de biodiesel soja, mamona e hisrocarbonetos monoaromáticos em ambientes aquáticos. Santa Catarina, Brazil, 89p. (M. Sc. Dissertation. Universidade Federal de Santa Catarina).

Montagnolli, R. N.; Lopes, P. R. M.; Bidoia, E. D. (2009) Applied models to biodegradation kinetics of lubrificant and vegetable oils in wastewater. Internacional Biodeterioration \& Biodegradation, 63, 297-305. http://dx.doi.org/10.1016/j.ibiod.2008.10.005

Nakano, O.; Neto, S.S.; Zucchi, R.A. (1981). Entomologia econômica (1 ${ }^{\text {st }}$ ed.). Piracicaba: Livroceres. 


\section{Macrothink}

NASA- National Aeronautics and Space Administration (2001). Building a Winogradsky Column. [Online] Avaliable at: <http://quest.nasa.gov> (April 20, 2012).

Parra, O. O. \& Bicudo, C. E. M. (1996). Introduction of landwater algae biology and systematic $\left(1^{\text {st }}\right.$. ed.). Santiago: Grafica Andes.

Parra, O. O. \& Bicudo, C. E. M. (1996). Introduction of landwater algae biology and systematic $\left(1^{\text {st }}\right.$. ed.). Santiago: Grafica Andes.

Sousa, M.L.; Moraes, P.B.; Lopes, P.R.M.; Montagnolli, R.N.; Angelis, D.F.; Bidoia, E.D. (2012). Textile dye treated photoelectrolytically and monitored by Winogradsky columns. Environmental Engineering Science, 29, 180-185. http://dx.doi.org/10.1089/ees.2010.0259

Trainor, F.R.; Shubert, L. E. (1983). Algae as Ecological Indicators (1st ed.). United Kingdom: Academic Press.

\section{Copyright Disclaimer}

Copyright reserved by the author(s).

This article is an open-access article distributed under the terms and conditions of the Creative Commons Attribution license (http://creativecommons.org/licenses/by/3.0/). 